\title{
D'Alembert or on the Good Physics
}

\author{
Giuseppe Boscarino \\ Cultural Association “S. Notarrigo", The Italic School, Sortino, Italy \\ Email: gpp.bos@libero.it
}

How to cite this paper: Boscarino, G. (2019). D'Alembert or on the Good Physics. Advances in Historical Studies, 8, 192-198. https://doi.org/10.4236/ahs.2019.85014

Received: December 17, 2018

Accepted: November 8, 2019

Published: November 11, 2019

Copyright (c) 2019 by author(s) and Scientific Research Publishing Inc. This work is licensed under the Creative Commons Attribution International License (CC BY 4.0).

http://creativecommons.org/licenses/by/4.0/

\begin{abstract}
We analyze, through writings of d'Alembert, the complex relationships that mathematics, physics and metaphysics entertain with man's faculties and their linguistic manifestations and highlight critical issues and philosophical and epistemological consistency, which we consider valid and actual. For the illuminist d' Alembert all good physical science is established and developed on a good philosophy and vice versa, as any good philosophy must be consolidated on a good metaphysics, to fertilize then good science. A well-structured science can then only be founded on a well-constructed language. Then the good metaphysics is above all critical of abusive and badly constructed languages, confused, quirky, nominalistic, empty, contradictory, when they hypostatize or reify mere names (force, cause, infinitesimal, infinite, axiom), they transform mere relations between simple physical properties in physical entities (velocity, acceleration, differential) or exchange names for questions about physical realities (the querelle about living forces), generic and vague names (being, substance, idea) for metaphysical principles (Plato, Aristotle, Scholastic).
\end{abstract}

\section{Keywords}

Mathematics, Physics, Metaphysics and Language

\section{Introduction. Undervaluation of the Figure of d'Alembert and His Revaluations}

For M. Paty, d'Alembert's work generally did not receive sufficient attention and a careful and deserving evaluation on the part of historians and philosophers (Paty, 1998). For P. Crépel this personage is still little known. A great way still separates us from benefiting from a knowledge of d'Alembert commensurable with the one we have of Voltaire, Diderot, Euler. From about thirty years d'Alembert's study has become more stimulating (Pierre, 2006). Today some are insisting on novelties in d'Alembert's scientific work and his philosophical her- 
itage. For Crêpel we owe him the Principle of Dynamics, the invention of the equations to partial derivates, solutions to the problem of vibrating strings. ùIn pure mathematics, contributions to the integral calculus are attributed to him. From the general point of view, the fertility of his many doubts and objections is recognized to him. But above all, it is recognized to him esprit critique et de critique (Pierre, 2006: p. 22). Finally, for Paty it is great that his importance as a scientist and philosopher for the history of science and philosophy, for the new relationship between the sciences and philosophy and for the place of epistemology now conceived as an autonomous science. He represents the ideal of the union de l'ecrivain et du savant. His spirit is animated by a strong universalist humanitarianism. From a philosophical-epistemological point of view, his is a rationalistic realism (Paty, 1998: p. 196).

\section{What Is the démarche in the Dalembertian Thought?}

In criticism it was debated: The Dalembertian démarche goes from a primitive scientific practice, Traité de dynamique, 1743, to move on to a more philosophical and informative practice of the Discours préliminaire de P Encyclopedie 1751, Essai sur les elements de philosphie, 1758, or vice versa? (Le Rue, 1994, Paty, 1998). We believe that a unique démarche accompanies d'Alembert's thought, the "mathematical" one, but understood in its original Greek, Pytha-

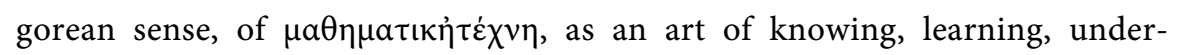
standing, wanting to practice the $\mu \dot{\alpha} \theta \eta \sigma \iota \varsigma$, the knowledge of reality, that he, as a $\mu a \theta \eta \mu a \tau$ «ó, , indicates from time to time healthy or good science, healthy or good physics, healthy or good philosophy, healthy or good metaphysics. Let's read some of his indications written in this sense that can make us grasp the Dalembertian démarche to try then maybe to interpret it:

A good philosophy is based on facts. In physics the only and true way of philosophizing consists in the application of the mathematical analysis to the experiences. Philosophy cannot be the science of ideas. Philosophy is either science of facts or that of chimeras and it would properties of being or in those of mode and substance ... In a healtly philosophy the first thing to do is to proceed to their elimination. (L'Encyclopedie, Discours préliminaire)

Here his critique of all Platonism or Neoplatonism and Aristotelianism appears clear. Therefore some literature of his Neoplatonic démarche cannot be shared (Le Rue, 1994).

Some great men, at the head of whom we must put Democritus, were successfully dedicated to the observation of nature. (L'Encyclopédie, Experimental). Here, however, the attention to Democritus appears, but not deepened through a critical reading of his fragments and testimonies. However, his limitation appears: a superficial reading of ancient Greek science and philosophy. The sensitive knowledge for D'Alembert is obscure and confusing, it is a question of abstracting from it the simplest, evident elements or properties and their equally 
simple and clear relationships and through them discover the most hidden ones. Tel est le but que le physicien doit se proposer, telles son les vîes par les-quelles il peut se montrer vraiment philosophe. (D'Alembert, Traité de l equilibre et de movement des fuides, Preface, III, 1754); ... la méthode mathématique est celle de toutes les sciences, celle qui est naturelle à Pesprit humain, celle qui fait découvrir les vérités de tout genre (Methode, L'Encyclopédie).

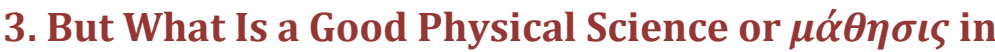 d'Alembert?}

The good physical science for d'Alembert is the science of facts, understood as the science of the relations between quantifiable properties, abstracted from sensible observation through the use of the senses and composed through imagination and the use of reason. These are conceived as ideas or elements, simple if of only properties, complex if of related sets of properties, reified through a clear and distinct language, divided between definitions, principles and consequences, which is the language of mathematics, built through social confrontation, are verified or falsified in turn by experience.

Use of the imagination is made by the inventors in the rules of calculation. But it is up to the philosophers how much they have imagined by calculating, making use of reason, but kept partly hidden or not expressed, expliciting the simple and luminous metaphysics that they have employed in their language. This creative imagination, even if of different kinds, unites the great geniuses of the past (Archimedes-Omer). Science is therefore a product of the use of senses, of imagination and of reason, of mathematical language and of social confrontation. Without their good use there are chatter, ghosts, absurd hypotheses, captious disputes, empty nominalisms. In short, there is a bad use of senses, of imagination, of reason, of language, of philosophical and social confrontation. Sensitive evidences are changed for true evidences or axioms. One falls into abuse when metaphysical reasoning and sensitive evidences are employed, not wanting to use calculation and analysis, when one wonders which shorter line employs a body that falls in the shortest possible time. Only an exact analysis of a good surveyor, who does not have the misfortune of being a metaphysician with little geometry, shows that it is a curved line, dissipating the paradox that although the straight line is shorter than the curve between two given points, the body that falls it takes it in less time. Ghosts are imagined. As in the case of the infinitesimal calculus in which we imagine existing infinitesimals and infinities, while it deals only with finite differences and finite relationships of finite differences and of limits of finite relationships. Not always to a good language corresponds a good metaphysics, as in the case of Leibnitz, while the opposite happens in Newton, both inventors of the infinitesimal calculus.

Newton est parti d'un autre principe; \& l'on peut dire que la métaphysique de ce grand géometre sur le calcul des fluxions est très-exacte \& très-lumineuse, quoiqu'il se soit contenté de la faire entre-voir. Il n'a jamais regardé le calcul 
différentiel comme le calcul des quantités infiniment petites, mais comme la méthode des premieres \& dernieres raisons, c'est-à-dire la méthode de trouv-

er les limites des rapports. (L’Encyclopédie, D’Alembert, Differentiel)

Not always to a strong imagination corresponds a good use of reason, as in the case of Descartes, a philosopher of great imagination (ib. Discours préliminaire), who, denying the existence of emptiness, ends up denying the existence of movement, and with to admit the existence of the vortices, then fails to explain the laws of the movement of the planets. Not always reason then uses imagination, the logic and the language well. See on the cause-effects report. It is false to imagine that the same cause must necessarily produce similar effects. It is the case of the false question of living forces. For if it is true that to similar effects correspond similar causes, it is not the contrary that to not similar effects must correspond not-similar causes, the thing is denied by the living forces, which, despite being the same, the cause produces not-similar effects (D'Alembert, 1990: pp. XXII-XXII). Therefore it is on the good use of the language that science is built as it is on its bad use that mystifications and overpowers are consumed in confrontation-social conflict. The Paty rightly wrote about it: The language was in his eyes the knot around which philosophy, mathematics and natural science weave their representation, influenced in that by the Condillac, for which $A$ well treated science is nothing but a well-made language (Paty, 1998: p. 132).

It is the conceptual simplicity of their object together with their linguistic clarity that makes mathematics capable of proofs, of certain demonstrations. They then become progressive if they update their language. Mathematics is a language, but cannot be that synthetic geometry of the Archimedes and Galileo, of Descartes and Newton, who, while innovating, still remain entangled, but the analytical one, which gives more importance to the physical relationships, which are properties of algebra and analysis, which to the physical figure. See what d'Alembert writes about the good physical science of the "mechanical movement" about the complex mediations that are realized in it through the language of algebra and analysis making good use of observation, imagination and reason (L'Enciclopédie, Discours, Elements des sciences, Mechanique).

\section{What the Meaning of Epistemology in d'Alembert and What the Relationships between Metaphysics, Philosophy and Science}

The epistemology of d'Alembert is the epistemology of simplicity and of elements, if we want to distinguish it from what today is called epistemology of complexity and complex systems. It is epistemology of definitions, not axioms. These as false evidences are sterile, obscure, puerile, as is the case with the word exist, which is reified, not being a physical property, but only an abstraction, a mere linguistic property (D'alembert 1986: p. 27).

However, the element has no metaphysical meaning, of the Aristotelian, but 
epistemological type. It is an idea, defined within the theory, half real and half nominal; once again the concept of definition is not of the Aristotelian type, in short it is a logos teoretikos, to recall instead a lexicon of Democritean type (Democrito, 1970: p. 296). It is an epistemology that is built on a metaphysical logic of opposites or complementaries, of Pythagorean type. Like when with imagination he distinguishes two types of extension, the one penetrable, the other as non-penetrable, which is the idea of body. From this he derives again that relative to the reciprocal action of the bodies, hence the laws of equilibrium and movement. In short, the object of Mechanics (L'Enciclopédie, Mechanique). Reality is a great, uninterrupted chain of beings, of which we cannot have complete knowledge, but only of traits, of which we can know the beginnings and of some we can know the points of union (D'Alembewrt, 1986: pp. 25-26). Sciences are then an immense labyrinth, but without mysteries, formed only of tracts of truth. Leaving the metaphysics of essences of extension, of movement, of force, etc., that is a metaphysics so dark, as useless and sterile, healthy physical science deals only with the properties of observation alone, where all men of common sense and all sects of the philosophers, thanks to clear and precise definitions, agree, without having found contradictions in their limited deductive chains.

To deny the knowledge of the essence or of the "thing in itself" and to say, affirming limits and possibilities of human knowledge, that in d'Alembert there is an element of Kantism and not vice versa that there is an element of d'alembertism in Kant, all wrapped up again in the cloud of an obscure metaphysics of a priori forms, is an absurd mystification. The healthy philosophy is that healthy metaphysics, which deals with "la tete de chaque portion de la chaine", which he calls principles. A general metaphysics makes no sense, while a particular metaphysics of every branch of sciences makes sense. There is no science that does not have its Metaphysics. ... La Philosophie n'est point destinée à se perdre dans les propriétés générales de letre et de la substance, ... elle est la Science des faits, ou des chimedres. ... Les saines idées metaphisiques sont des vérités comunes que chacun saisit, mais que peu d hommes ont le talent de developer (D'Alembert, 1986).

The good principles or causes are not to be seen from outside or inside or from the top of sensitive observations, but from their sensitive effects, to which we can trace back through rational and mathematical discourses, which use measurable, finite quantities or properties, even when apparently for mere linguistic game these ones seem to use the terms of infinity or infinitesimal, but of which we cannot know the true nature. And first principles cannot contradict principles of reason and of good observation, because in that case they would merely be contingent truths, but not necessary, whose characteristic can only be agreed with reason and observation. Nor they can escape the social confrontation of physical experiments and logical-linguistic and mathematical demonstrations among experts. Philosophies and twentieth-twentieth-century sciences, such as Positivism and Neo-positivism, are deceived to be able to separate phi- 
losophy from science, and science from metaphysical, maybe landing then in comminglings between them of irrationalistic type, "everything goes well". The Dalembertian démarche is immune to ingenuous anti-metaphysics, vulgar scientism, flat positivism, superb idealism. Neither d'Alembert is a mere anticipator of the obscure methaphisics of science of a priori Kantian forms, of Hegelian idealism, of Comtian positivism (Paty. 1998: p. 197).

The fact is, as rightly Paty concludes his work on d'Alembert, that the work of D'Alembert has not yet received, in general, from the historians and philosophers sufficient attention. And there is a metaphysics in the strong sense in d'Alembert, who still can do today to demarche in philosophical and scientific research? This is given by the principle of reason, which excludes and criticizes ante litteram every metaphysics of chance or chaos, hypostatized in nature as a unifying element and creator, as is written today by philosophers scientists, such as the Prigogine, similar to that evoked from some pre-Socratics, a fecund chaos, from which potentially different structures can emerge (Prigogine \& Stengers, 1993). This is still given by the logical-imaginative principle of conceptual simplicity and linguistic clarity, which is not only his epistemology, but also his illuministic pedagogy of matemthikòs. See the case of the scientist philosopher Heisemberg at the time when he places the confused, polymorphic Aristotelian concept of dynamis at the base of the quantum mechanics (Boscarino, 2000). What then is good philosophy or mathesis or good physics for d'Alembert? Good philosophy is above all criticism of abusive and badly constructed, confused, quirky, nominalistic, empty, contradictory languages, when they hypostatize or reify mere names (force, cause, infinitesimal, infinite, axiom), they transform mere relations between simple physical realities in physical entities (velocity, acceleration, differential) or exchange questions of names for questions about physical realities (the querelle on the living forces), generic and vague names (being, substance, idea) for metaphysical principles (Plato, Aristotle, the Scholastic). Here is the still present philosophical and epistemological significance of Dalembertian thought. About reifying mere names (strength) or mere relations between properties (velocity), on which we must think if not in terms of effects, or to overcome obstacles or resistance to other bodies, and not in terms of presumed or fantastic causal entities, see what d'Alembert writes (D’Alembert, 1990: pp. XVIII-XIX).

\section{Conclusion. Is There the Ancient Greek Thought in the Modern, for Us Current, Dalembertian démarche?}

D'Alembert thinks of reconstructing his philosophical-epistemological thought starting from the modern Bacons, Loke, Descartes, Newton, Leibnitz, and so it is thought by scholars, today, such as A.R.E. Oliveira, 2017, and Paty, in reality he is trying to reconstruct the ancient linguistic-philosophical-epistemological tradition of thought of the Pythagoras, the Parmenides, the Democritus, Archimedes, which was destroyed by another tradition of thought, the Platonic-Aristotelian tradition, continued by the Scholastic (Boscarino, 2016). D'Alembert 
writes: Newton finally appeared and was the first to demonstrate what his predecessors had only glimpsed the art of applying geometry to physics, and to erect, combining experience and calculation, an exact, deep, luminous new science. (Discours) But even Newton himself had to recognize in his Principia that according to Pappus' testimony, the ancients had the highest consideration of mechanics ... and founded a double mechanics: the rational, which proceeds by very acute demonstrations, and the practice (Newton, 1965: p. 65).

\section{Acknowledgements}

The author wishes to express his gratitude and appreciation to Prof. Armando Anzaldo for his assistence and advice about English translation.

\section{Conflicts of Interest}

The author declares no conflicts of interest regarding the publication of this paper.

\section{References}

Boscarino, G. (2000). Quantum Mechanics: The Real and the Possible. In C. Garola, \& A. Rossi (Eds.), The Foundations of Quantum Mechanics (pp. 73-81). Singapore: World Scientific. https://doi.org/10.1142/97898127935600005

Boscarino, G. (2016). Tradizioni di pensiero. La tradizione filosofica italica della scienza. Roma: Aracne.

D’Alembert, J. (1986). Essai sur les éléments de philosophie. Fayard.

D’Alembert, J. (1990). Traité de dynamique. Sceaux: Editions Jacques Gabay.

Democrito (1970). Raccolta dei frammenti. Milano: Bombiani.

L'Encyclopédie/1re édition-Wikisource, Internet. (Discours préliminaire, Elemens des sciences, Expérimental, différentiel, limite, infiniment petit, infini).

Le Rue, V. (1994). D’Alembert philosophe. Paris: Librairie philosophique J. Vrin.

Newton, I. (1965). Principi matematici di filosofia naturale. Torino: UTET, Prefazione dell'autore, 1686.

Oliveira, A. R. E. (2017). D'Alembert: Between Newtonian Science and the Cartesian Science Inheritage. Advances in Historica Studies, 6, 128-144. https://doi.org/10.4236/ahs.2017.64010

Paty, M. (1998). D’Alembert ou la raison physico-mathématique au siècle des Lumières. Paris: Les belles lettres.

Pierre, C. (2006). Qu'y a-t-il de nouveau dans l'oeuvre scientifique de D’Alembert.

Prigogine, L., \& Stengers, I. (1993). La nuova alleanza. Metamorfosi della scienza. Torino: Einaudi. 